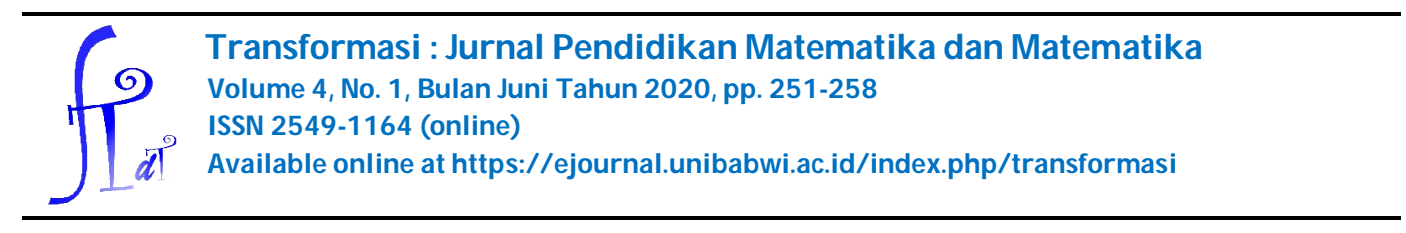

\title{
PROSES PENYEBARAN KONDUKSI PANAS 1-DIMENSI PADA PIPA BESI
}

Rofila El Maghfiroh', Muhammad Badaruz Zaman ${ }^{2,3}$

1Jurusan Teknik Sipil, Politeknik Negeri Malang

2Jurusan Teknik Elektro, Politeknik Negeri Malang

3Jurusan Teknik Mesin, Universitas Yudharta Pasuruan

Email korespondensi : rofila.elma@gmail.com

Diterima : 28-05-2020, Revisi: 14-06-2020, Diterbitkan : 26-06-2020

\begin{abstract}
ABSTRAK
Dalam aplikasi bidang teknik, sangat sering digunakan bahan logam terutama besi sebagai bahan pembuatan pipa. Salah satu manfaat pipa besi yaitu dalam proses transfer gas. Dalam proses tersebut, gas serta pipa transfer sangat rentan terhadap panas.
\end{abstract}

Skema beda hingga yang diterapkan pada metode numerik Crank-Nicoson memiliki tingkat ketelitian yang sangat baik. Skema tersebut digunakan untuk analisis proses penyebaran konduksi panas pada pipa besi yang berisi gas oksigen.

Proses penyebaran panas pada pipa besi terjadi dengan mempertahankan syarat batas yang telah ditentukan.

Kata kunci : pipa besi, transfer gas, penyebaran konduksi panas, metode numerik Crank-Nicolson.

\footnotetext{
ABSTRACT

Metal is also used widely in engineering applications, in particular iron as a substitute for pipes. Gas transfer process is one advantage of the iron pipe. During the process, gas and transfer pipes are highly exposed to heat.

Finite difference scheme is applied to Crank-Nicolson numerical method have a very high degree of accuracy. The scheme is used for analysis process of conduction heat transfer on iron pipes containing oxygen gas.

The heat transfer process in an iron pipe occurs by maintaining the specified boundary conditions.
}

Keywords : iron pipe, gas transfer, conduction heat transfer, Crank-Nicolson numerical method.

\section{Pendahuluan}

Logam banyak dipakai untuk berbagai macam keperluan teknik, misalnya sebagai bahan struktur, pintu, jendela dan pipa. Dari kebanyakan bahan logam, besi merupakan bahan yang paling banyak digunakan. Salah satu alasannya karena kebutuhan bahan baku industri besi baja di Indonesia cukup besar (Haryadi \& Saleh, 2012), 
contohnya dalam industri pembuatan tiang listrik, konstruksi jembatan, pintu air, kerangka bangunan dan sebagainya (Amrin \& Ardilla, 2013). Besi diperoleh dari tambang biji besi dalam bentuk oksida besi $\left(\mathrm{Fe}_{2} \mathrm{O}_{3}\right)$. Jumlah kandungan besi dalam biji besi tergantung dari tempat pengambilannya dan biasanya bercampur dengan bahan-bahan lain, misalnya silika $\left(\mathrm{SiO}_{2}\right)$, alumina $\left(\mathrm{Al}_{2} \mathrm{O}_{3}\right)$, mangaan, belerang, fosfor, dll (Nurlina, 2011). Besi tahan karat memiliki banyak karakteristik yang dapat dimanfaatkan dalam berbagai aplikasi konstruksi. Selain itu, besi tahan terhadap korosi dan tahan lama, hal ini memungkinkan struktur lebih tahan lama. Dalam bidang arsitektur, bentuk dan warna besi mudah untuk diperhatikan. Besi juga merupakan bahan yang tangguh (Baddoo, 2008). Pada suhu ruangan atau suhu tinggi, karakteristik besi tahan karat berbeda dengan besi karbon, hal ini dikarenakan kandungan paduannya juga berbeda. Pada struktur, pada kondisi kebakaran, sifat dari besi tahan karat dan karbon sangat bermanfaat. Khususnya besi karbon, mempunyai kekuatan dan ketahanan oksidasi pada suhu tinggi (Gardner, dkk., 2010).

Penyebaran panas pada pipa besi merupakan salah satu contoh dari perpindahan panas konduksi, dimana perbedaan suhu pada benda padat terjadi dikarenakan panas yang mengalir dari daerah dengan suhu yang lebih tinggi ke daerah yang mempunyai suhu lebih rendah (Kreith, dkk., 2011). Konduksi panas dapat diilustrasikan pada gambar berikut ini.

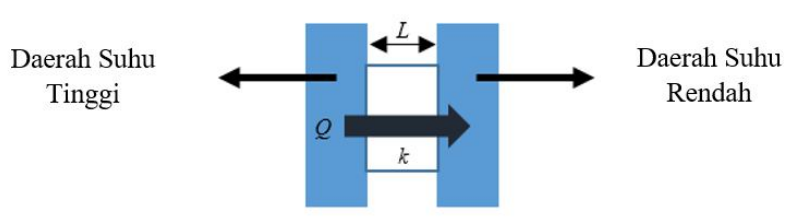

Gambar 1. Ilustrasi Perpindahan Panas Konduksi

$\mathrm{Q}$ adalah panas yang dipindahkan, $\mathrm{L}$ adalah ketebalan bahan dan $\mathrm{k}$ adalah konstanta konduktivitas termal (Halliday, dkk., 1997). Berikut ini merupakan konstanta konduktivitas termal pada beberapa material dan gas.

Tabel 1. Konstanta Konduktivitas Termal (Sumber: Polezhaev \& Yury, 2011)

\begin{tabular}{lc|ll}
\hline & W/ $\mathrm{m} \cdot{ }^{\circ} \mathrm{K}$ & \multicolumn{2}{c}{$\mathrm{W} / \mathrm{m} .{ }^{\circ} \mathrm{K}$} \\
\hline METALS & & \multicolumn{2}{|l}{ GASES } \\
\hline Silver & 429 & Hydrogen & 0,1655 \\
\hline Copper & 403 & Helium & 0,1411 \\
\hline Iron & 86,5 & Oxygen & 0,0239 \\
\hline Tin & 68,2 & Nitrogen & 0,0237 \\
\hline Lead & 35,6 & Air & 0,0226 \\
\hline
\end{tabular}

Dalam proses transfer gas sering digunakan pipa besi sebagai media transfer. 
Pipa merupakan media dalam mengalirkan fluida seperti minyak, gas, atau air dalam jumlah yang sangat besar dan jarak yang jauh (Wibowo, 2015). Pipa besi serta gas tersebut sangat rentan terhadap suhu, karena memiliki kemampuan untuk menghantarkan panas secara konduksi.

Pada penelitian ini, dibahas proses penyebaran panas pada pipa besi yang berisikan gas oksigen dengan pendekatan numerik, dengan tujuan mengetahui panas pipa besi dan gas oksigen ditiap level waktu. Penyebaran panas ditentukan dengan asumsi panas tidak merambat secara konveksi pada gas dan pipa yang digunakan adalah pipa lurus 1-dimensi. Metode numerik yang digunakan adalah metode Crank-Nicolson dengan memperhatikan skema beda hingga pusat pada variabel waktu dan ruang. Hal ini dikarenakan metode Crank-Nicolson merupakan metode beda hingga yang dapat digunakan untuk menyelesaikan persamaan panas dan persamaan diferensial parsial lainnya, selain itu metode Crank Nicolson merupakan metode yang stabil tanpa syarat dan mempunyai tingkat akurasi tinggi (Fadugba, dkk., 2013).

\section{Metode Penelitian}

Persamaan konduksi panas dapat diaplikasikan untuk menganalisis perpindahan panas secara konduksi, contohnya untuk mengetahui penyebaran panas yang terjadi pada material logam (Maghfiroh, dkk., 2019). Pada penelitian ini, akan dibahas proses penyebaran panas pada pipa besi yang berisikan gas oksigen secara numerik. Sedemikian sehingga perlu diperhatikan persamaan konduksi panas satu dimensi berikut ini (Morton, 2005).

$$
\mathrm{u}_{\mathrm{t}}=\mathrm{u}_{\mathrm{xx}}
$$

Secara umum, persamaan konduksi panas pada persamaan (1) mempunyai syarat awal :

$$
\mathrm{u}(\mathrm{x}, 0)=\mathrm{u}_{0}(\mathrm{x})
$$

serta syarat batas :

$$
\mathrm{u}(0, \mathrm{t})=\mathrm{u}(1, \mathrm{t})=0
$$

solusi numerik persamaan konduksi panas satu dimensi dengan syarat awal dan syarat batas tersebut dapat ditentukan menggunakan skema pendekatan Crank-Nicolson, karena metode tersebut mempunyai tingkat akurasi yang tinggi.

Pendekatan turunan pertama terhadap variabel waktu pada persamaan (1) ditentukan dengan skema pendekatan beda hingga pusat, sehingga diperoleh skema pendekatan berorde dua terhadap variabel waktu, sebagai berikut :

$$
\left.\frac{\partial \mathrm{u}}{\partial \mathrm{t}}\right|_{\mathrm{t}_{\mathrm{n}+\frac{1}{2}}}=\frac{\mathrm{u}_{\mathrm{i}}^{\mathrm{n}+1}-\mathrm{u}_{\mathrm{i}}^{\mathrm{n}}}{\Delta \mathrm{t}}+\mathrm{O}\left(\Delta \mathrm{t}^{2}\right)
$$

Pendekatan turunan kedua terhadap variabel ruang pada persamaan (1) diten- 
tukan dengan skema pendekatan beda hingga pusat, sehingga diperoleh skema pendekatan berorde dua terhadap variabel ruang, sebagai berikut :

$$
u_{i}^{\prime \prime}=\frac{u_{i-1}-2 u_{i}+u_{i+1}}{h^{2}}+O\left(h^{2}\right)
$$

Skema pendekatan turunan pertama terhadap variabel waktu dan skema pendekatan turunan kedua terhadap variabel ruang disubstitusikan ke persamaan (1), sedemikian sehingga didapatkan suatu skema pendekatan Crank-Nicolson sebagai berikut :

$$
\mathrm{W}^{(\mathrm{n}+1)}=\left((\mathrm{I}+\lambda \mathrm{A})^{-1}(\mathrm{I}-\lambda \mathrm{A})\right) \mathrm{W}^{(\mathrm{n})}
$$

Dengan I adalah matriks identitas, $\lambda=\frac{\Delta t}{2(\Delta x)^{2}}$, dan A adalah matriks berikut.

$$
A=\left[\begin{array}{ccccccc}
2 & -1 & 0 & & \cdots & & 0 \\
-1 & 2 & -1 & 0 & & & \\
& & & & & & \vdots \\
\vdots & & & & & & \\
& & & 0 & -1 & 2 & -1 \\
0 & & \cdots & & 0 & -1 & 2
\end{array}\right]
$$

Skema pendekatan Crank-Nicolson pada persamaan (4) berordo dua terhadap variabel waktu dan juga terhadap variabel ruang (Humi, 1992). Dengan demikian skema pendekatan Crank-Nicolson akan memberikan solusi numerik dengan tingkat ketelitian yang sangat baik.

\section{Hasil dan Pembahasan}

Dalam menentukan proses penyebaran panas pada pipa besi berisikan gas oksigen, perlu diperhatikan beberapa hal, yaitu pipa besi yang digunakan memiliki panjang $\mathrm{L}$ dengan luas penampang melintang yang sama di setiap titik, yaitu A, serta terdapat sumber panas dan sekeliling permukaan pipa besi diisolasi. Luas penampang A berisikan gas oksigen. Diasumsikan kondisi awal dan kondisi ujung pipa besi yang berisi gas oksigen telah ditentukan. Selain itu, penyebaran panas pada pipa besi yang berisikan gas oksigen diasumsikan terjadi secara konduksi 1-dimensi dan penyebaran panas tidak merambat secara konveksi pada gas.

Kondisi tersebut sesuai dengan persamaan konduksi panas satu dimensi berikut : 


$$
u_{t}=u_{x x}+2 t+x(1-x)
$$

dengan syarat awal :

$$
\mathrm{u}(\mathrm{x}, 0)=1-\mathrm{x}-\frac{1}{\pi} \sin (2 \pi \mathrm{x})
$$

serta syarat batas :

$$
u(0, t)=1, u(1, t)=0
$$

solusi numerik persamaan konduksi panas satu dimensi dengan syarat awal dan syarat batas tersebut dapat ditentukan menggunakan skema pendekatan Crank-Nicolson (Bradie, 2006).

Skema pendekatan yang digunakan dalam menentukan solusi numerik pada persamaan (5) sedikit berbeda dengan skema pendekatan pada persamaan (4). Hal ini dikarenakan pada persamaan (5) syarat batas yang digunakan adalah syarat batas Dirichlet tak nol dan terdapat sumber panas yaitu $s(x, t)=2 t+x(1-x)$. Skema pendekatan yang selanjutnya akan digunakan adalah sebagai berikut :

$$
\begin{aligned}
\mathrm{W}^{(\mathrm{n}+1)}= & \left((\mathrm{I}+\lambda \mathrm{A})^{-1}(\mathrm{I}-\lambda \mathrm{A})\right) \mathrm{w}^{(\mathrm{n})}-(\mathrm{I}+\lambda \mathrm{A})^{-1} \lambda\left(\mathrm{SB}^{(\mathrm{n})}+\mathrm{SB}^{(\mathrm{n}+1)}\right) \\
& +(\mathrm{I}+\lambda \mathrm{A})^{-1} \frac{\Delta \mathrm{t}}{2}\left(\mathrm{SP}^{(\mathrm{n})}+\mathrm{SP}^{(\mathrm{n}+1)}\right)
\end{aligned}
$$

Dengan $\mathrm{w}^{(\mathrm{n})}$ adalah syarat awal, $\mathrm{SB}^{(\mathrm{n})}$ syarat batas saat $\mathrm{t}=\mathrm{t}_{0}$ dan $\mathrm{SP}(\mathrm{n})$ adalah sumber panas saat $t=t_{0}$.

Gambar berikut ini merupakan solusi numerik persamaan (5) dengan syarat batas dan syarat awal. Persamaan (5) diaplikasikan pada pipa besi yang berisikan gas oksigen. Diperhatikan konstanta konduktivitas termal besi adalah $\mathrm{k}=86,5$ $\mathrm{W} / \mathrm{m}^{\circ} \mathrm{K}$ atau setara dengan $2,076 \times 10^{-2} \mathrm{kcal} / \mathrm{s} . \mathrm{m}^{\circ} \mathrm{K}$, sedangkan konstanta konduktivitas termal untuk gas oksigen adalah $\mathrm{k}=0,0239 \mathrm{~W} / \mathrm{m}^{\circ} \mathrm{K}$ setara dengan $5,736 \times$ $10^{-6} \mathrm{kcal} / \mathrm{s.m}^{\circ} \mathrm{K}$ ( sesuai Tabel 1 ).
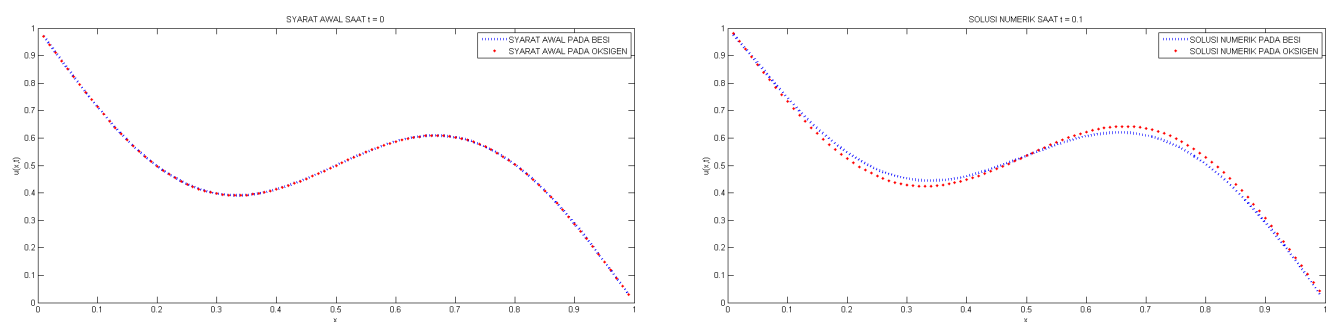

Gambar 2. Solusi Numerik Persamaan (5) saat Syarat Awal dan Saat t =0,1

Berdasarkan gambar 2, syarat awal yang digunakan pada penyebaran panas pipa besi sama dengan syarat awal pada penyebaran panas gas oksigen. Terjadi perbedaan penyebaran panas pada pipa besi dan gas oksigen saat $t=0,1$. Akan tetapi pe- 
nyebaran panas tetap mempertahankan syarat batas pada keduanya. Gambar selanjutnya adalah solusi numerik persamaan (5) saat $t=0,2$ dan $t=0,3$.
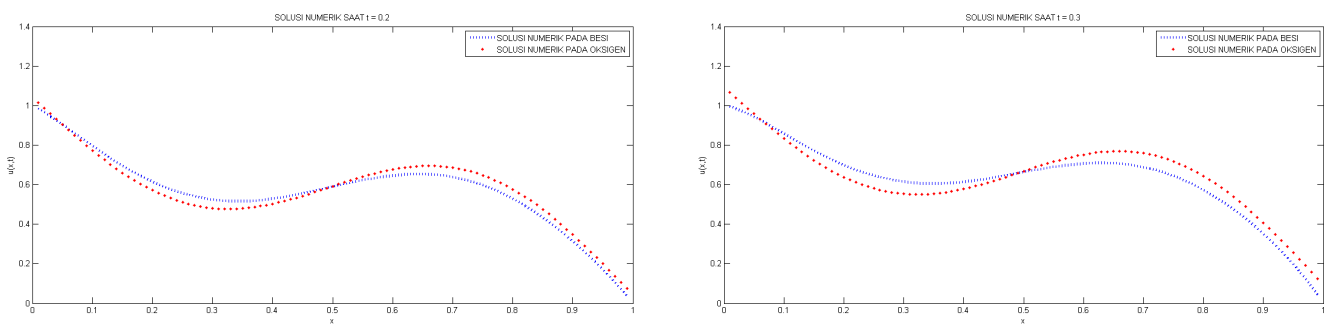

Gambar 3. Solusi Numerik Persamaan (5) saat $t=0,2$ dan saat $t=0,3$

Gambar 3 merupakan solusi numerik persamaan (5) pada pipa besi dan gas oksigen di waktu yang berbeda yaitu saat $t=0,2$ dan $t=0,3$. Berdasarkan gambar tersebut, grafik solusi numerik dipengaruhi oleh syarat awal yang merupakan fungsi sinus dengan tetap mempertahankan syarat batas, meskipun pada gas oksigen terdapat perbedaan di ujung-ujung batasnya. Solusi numerik Persamaan (5) saat $t=0,4$ dan $t$ $=0,5$ adalah sebagai berikut.
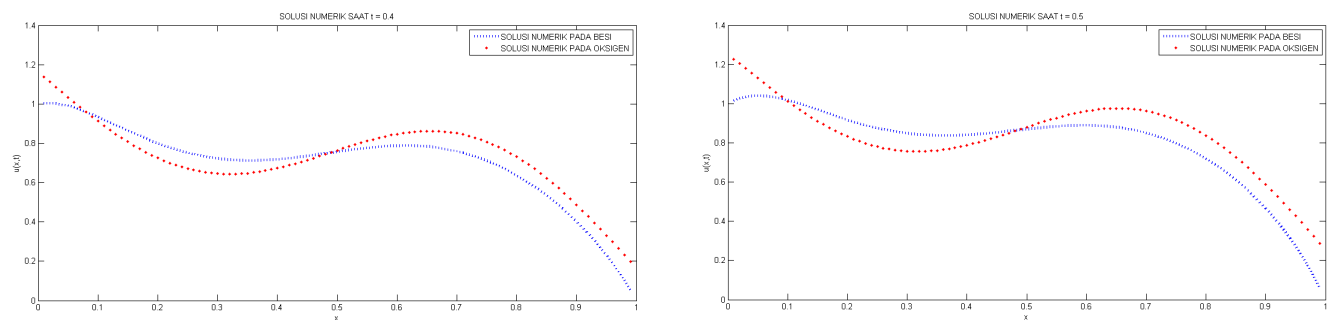

Gambar 4. Solusi Numerik Persamaan (5) saat $t=0,4$ dan saat $t=0,5$

Sesuai gambar 4, pada pipa besi, penyebaran panas tetap mempertahankan syarat batas di setiap penambahan level waktu. Hal ini berbeda dengan penyebaran panas pada gas oksigen, setiap penambahan level waktu, pada ujung-ujung batasnya semakin terlihat perbedaan dengan syarat batas. Kondisi tersebut dipengaruhi oleh penggunaan persamaan konduksi panas, syarat awal, syarat batas dan sumber panas yang sama pada pipa besi dan gas oksigen sedangkan panas akan terus terakumulasi seiring bertambahnya level waktu. Selain itu, pada gas oksigen hanya memperhatikan proses penyebaran panas secara konduksi dengan mengabaikan proses penyebaran panas secara konveksi.

\section{Kesimpulan}

Solusi numerik penyebaran panas pada pipa besi dan gas oksigen yang diperoleh dari skema pendekatan Crank-Nicolson dipengaruhi oleh konstanta konduktivitas 
termal, penggunaan persamaan konduksi panas, syarat awal, syarat batas dan sumber panas. Panas terus terakumulasi seiring bertambahnya level waktu. Proses penyebaran panas pada pipa besi terjadi dengan mempertahankan syarat batas yang telah ditentukan. Setiap penambahan level waktu penyebaran panas pada gas oksigen semakin terlihat berbeda dengan syarat batas pada ujung-ujung grafik. Hal ini dikarenakan pada gas oksigen hanya memperhatikan proses penyebaran panas secara konduksi dan penyebaran panas secara konveksi diabaikan.

\section{Ucapan Terima Kasih}

Terima kasih disampaikan kepada Politeknik Negeri Malang dan Universitas Yudharta Pasuruan yang telah memfasilitasi keberlangsungan penelitian dalam artikel ini.

\section{Daftar Pustaka}

Armin \& Ardilla, A. (2013). Analisis Besi (Fe) dan Aluminium (Al) Dalam Tanah Lempung Secara Spektrofotometri Serapan Atom. Prosiding Semirata FMIPA Universitas Lampung (pp. 17-22). Lampung : FMIPA Universitas Lampung.

Baddoo, N.R. (2008). Stainless Steel In Construction: A Review Of Research, Applications, Challenges, And Opportunities. Journal Constructional Steel Research 64, 1199-1206.

Bradie, B., 2006, A Friendly Introduction to Numerical Analysis, Perason Education, Inc., Jersey.

Fadugba, S. E., dkk. (2013). Crank Nicolson Method for Solving Parabolic Partial Diffrential Equations. International Journal of Applied Mathematics and Modeling, Vol. 1, No. 3, 8-23.

Gardner, I. dkk., 2010, Elevated Temperature Material Properties Of Stainless Steel Alloys, Journal Constructional Steel Research 66,634-647.

Halliday, D. dkk., 1997, Fundamental of Physics, Fifth Edition, John Wiley \& Sons, Inc., Canada.

Haryadi, H., \& Saleh, R., 2012, Analisis Keekonomian Bijih Besi Indonesia, Jurnal Teknologi Mineral dan Batubara, Vol.8, No.1, 1-16.

Humi, M. \& Miller, W.B., 1992, Boundary Value Problems and Partial Differential Equations, PWS-KENT Publishing Company, Boston.

Kreith, F., dkk., 2011, Principles Of Heat Transfer, Seven Edition, Cengage Learning, Inc., USA. 
Maghfiroh, dkk. (2019). Analisis Numerik Peyebaran Panas Pada Batang Baja 1-Dimensi Menggunakan Skema Beda Hingga Kompak. Prosiding Seminar Nasional Integrasi Matematika dan Nilai Islami, Vol.3, No.1, September 2019, (pp. 152-159). Malang: Universitas Islam Negeri Maulana Malik Ibrahim Malang.

Morton, K.W. \& Mayers, D., 2005, Numerical Solution of Partial Differential Equations, Second Edition, Cambridge University Press, New York.

Nurlina, S., 2011, Teknologi Bahan I, Bargie Media, Malang.

Polezhaev \& Yury V. (2011). Thermal Coductivity. TermopediaTM, A-to-Z Guide to Thermodynamics, Heat \& Mass Transfer, and Fluids Engineering. DOI: 10.1615/ AtoZ.t.thermal_conductivity.

Wibowo, F. (2015). Kajian Resiko Pipa Gas Transmisi PT Pertamina dengan Metode Dynamic Segmentation Approach Studi Kasus Simpang KM32 Palembang. Jurnal Teknik Sipil dan Lingkungan, Vol. 3, No. 1, 726-733. 